\title{
Australian Studies and Study Abroad
}

\author{
A n n C u r thoys
}

Australian National University

\section{Introduction}

In her challenging essay, "Anti-Area Studies," Tessa Morris-Suzuki outlines the history, strengths, and weaknesses of area studies. ${ }^{1}$ The idea of studying whole societies, or geo-cultural regions, emerged, she observes, in the mid-twentieth century, in the context of growing international tensions culminating in the Second World War. These tensions and the war itself made the value of area studies very clear: there was great strategic value in understanding the languages, histories, and cultures of one's potential enemies and allies. In the subsequent Cold War, knowledge of hitherto unfamiliar regions of the world was felt to be just as important. Increased economic links between different regions of the world also strengthened the desire to understand the culture and society of one's trading partners. Intellectually, scholars and teachers were challenged by the idea of interdisciplinary work-as required by area studies-especially within the humanities and social sciences.

The value of area studies, as scholars in one region study another, is now well known, and there has indeed been the growth in knowledge and understanding sought by the pioneers of the field. Scholars working in different disciplines have had to break out of their narrow specializations and take a broad approach to understanding cultures and societies. Yet, Morris-Suzuki argues, there are also problems with an area studies approach. Students of area studies tend to graduate with excellent knowledge of their area but insufficient grasp of the principles and methods of any one discipline, say history or anthropology. Furthermore, area studies tend to take the designation of an area- "Southeast Asia" or "Latin America" - for granted, and to give disproportionate emphasis to those aspects of an "area" which are common throughout it. Conversely, area 
studies give so much primacy to the analysis of phenomena within defined geographical regions that they do not help much with the investigation of those global forces for which geographical proximity matters relatively little.

Morris-Suzuki is particularly concerned with Asian studies. How useful is her analysis and critique for Australian studies? How valuable has Australian studies been for promoting understanding of Australian culture and society elsewhere? How has the trajectory of particular disciplines been affected? And is it marked by too great an emphasis on what is distinctive about Australian culture, and too little on what is shared with societies elsewhere?

\section{The Rise of Australian Studies for Australians}

Within Australia itself, Australian studies, as an example of area studies, emerged in the 1980s. This was not the beginning of the university study of Australia-examination of Australian language, literature, culture, politics, history, and society had long been emerging, especially after the Second World War. In my own discipline, history, some professors had turned their attention to Australian history in the earlier decades of the century, but the teaching of Australian history in universities became popular only in the 1950s, and in some places even later. In departments of English, courses in Australian literature emerged around the same time. As newer disciplines like sociology and political science gained ground in Australian universities in the 1970s, they promoted the study of Australian society and politics. Yet these developments were rather uneven, and by the early 1980s, the Australian government suspected that universities were providing an inadequate education about Australia for young Australians. The Committee to Review Australian Studies in Tertiary Education was established, and in its report in 1987 advocated a range of means whereby Australian content within the university curriculum could be encouraged and strengthened. It also advocated the development of an interdisciplinary approach to Australian studies. On its recommendation, a National Centre for Australian Studies was established at Monash University. ${ }^{2}$

Since that time, Australian studies programs have proliferated in 
many universities, and have also become an important part of distance learning programs. Sometimes these involve specially-developed interdisciplinary courses based on the area studies model, but very often they are programs in which courses offered by the disciplines on an aspect of Australia_say Australian history, or Australian literature-are combined together to form a multidisciplinary program. Usually, the growth of interdisciplinary programs has been in the smaller universities, which find it difficult to sustain large discipline-based programs in the humanities and social sciences. ${ }^{3}$ In the larger or older universities, the multidisciplinary approach, which preserves discipline-based courses, has prevailed. ${ }^{4}$ At the Australian National University, for example, where I am the coordinator, the undergraduate program links together into a sequence subjects taught by the disciplines of history, English, political science, sociology, anthropology, archaeology, linguistics, art history, and geography.

\section{Australian Studies for non-Australians}

Yet, as Morris-Suzuki points out, area studies have usually been developed for understanding not so much one's own society as for understanding societies other than our own. In these terms, as a field for scholars and students outside Australia, Australian studies still has a low profile.

There have been determined efforts to change this situation, especially with the establishment since the 1970s of Australian studies centres in Europe, Asia, and North America. 5 The initiative and support for these programs has come from a variety of sources. Sometimes, as in the United Kingdom and Japan, the role of the Australian government has been crucial, though overall its role has been modest compared to the support given by the Canadian and United States governments to their equivalent programs. At other times, for example in Italy and Denmark, programs have been developed by individual Australians overseas managing to gain some university support for teaching and research in Australian studies. On yet other occasions, notably in the United States and to a lesser extent Japan, foreign universities and governments have supported the development of Australian studies programs. Only very rarely have private foundations been involved, though the Menzies Foundation did rescue the Australian studies centre at the University of London when Australian government funding was reduced. Sometimes, centres have benefited from a combina- 
tion of these forms of support. All these centres and programs have been important in promoting Australian studies in their region. ${ }^{6}$

Australian studies centres overseas have usually found, however, that student interest in their courses has been modest. With its small population, relatively healthy economy, and fairly quiet politics, Australia for most of the world does not present significant economic or strategic threats or opportunities. It is not surprising, then, that the study of Australia has not been significant outside Australia itself. Despite the praiseworthy efforts of the proponents of Australian studies in Asia, Europe, and North America, international understanding of Australian culture and society is still extremely limited.

In this context, the growth of study abroad programs of various kinds has presented an exciting development for Australian studies. In these cases, foreign students come to Australia to study for periods ranging from several weeks to a year, and combine their studies here with travel and tourism, experiencing living in Australia as well as learning about it. These programs seem to be exciting much more interest in Australian studies than Australian studies programs abroad alone have been able to do. For English-speaking students, such as those from the U.S., Australia represents a relatively easy study abroad experience, along with the chance to see an ecology, flora, and fauna very different from that in the U.S., and to learn about a society at once very similar to, and yet different from, their own. For non-English-speaking students, it presents a chance to learn English relatively cheaply, and access educational opportunities that may not be available at home. From the Australian universities' point of view, teaching overseas students is a source of much-needed income. It also assists the effort of Australian universities to develop a more open and international learning culture.

\section{Too Much Coherence?}

To return to one of the questions raised by Morris-Suzuki: is an area study like Australian studies marked by too great an emphasis on what is distinctive about Australian culture, what seems to hold it together, and too little on what is shared with histories and societies elsewhere? Is it, as some have claimed, narrow and insular, or are more international and global approaches taken? 
In my view, Australian studies has at times indeed been enclosed and inward-looking, conducted largely by Australians for Australians. This was often in response to the older, very British, focus of scholarship and education in Australia, which — whether conducted by British immigrant or Australian-born scholars-did indeed undervalue Australian achievement and distinctiveness in favour of a desire for and appreciation of the culture and civilization of Europe. For many young scholars in the 1960s and 1970s, to study Australian culture in any depth was a rather radical act, a statement that perhaps Australian intellectuals should be doing more to foster knowledge and understanding of their own country.

Partly because of its origins in this reaction against (a self-imposed) British cultural domination, Australian studies seemed to be dogged by a stereotypical way of understanding its subject. The stereotypes are familiar-the idea of the quintessential Australian as white, relaxed, egalitarian, and anti-authoritarian, a kind of permanent Crocodile Dundee. These stereotypes have a long history, deriving from the nineteenth-century idea that every continent has its own natural environment and its own cultural spirit, and the turn-of-the-century idea that the spirit of a society was embodied in its rural, and not its urban, ways of life. The search for an identity which was distinctively Australian, and not some kind of pale imitation of Britain, was also a highly-gendered concern, a male creation story. Russel Ward, in The Australian Legend (1958), famously gave expression to ideals developed, he argued, in rural Australia, but later thought of as identifying Australians more generally:

According to the myth the typical Australian is a practical man, rough and ready in his manners and quick to decry any appearance of affectation in others. He is a great improviser, ever willing to have a go at anything, but willing to be content with a task done in a way that is near enough. (...). He swears hard and consistently, gambles beavily and often, and drinks deeply on occasion (...) be is usually taciturn rather than talkative. (...) he believes that Jack is not only as good as bis master, but, at least in principle, probably a good deal better, and so be is a great knocker of eminent people. ${ }^{7}$

Ward's typical Australian was represented and sustained in a number of important Australian films of the 1970s and 1980s-Jack Thompson in Sunday Too Far Away, Bryan Brown in A Town Like Alice, and, most 
famously, Paul Hogan in Crocodile Dundee.

This rather nationalistic emphasis persisted through the 1980s and into the $1990 \mathrm{~s}$, albeit in a rather perverse way. The task of Australian studies was now seen as the exposure of these images as mere stereotypes, with little relation to actual Australian experience, and the examination of how and why such stereotypes emerge and survive. ${ }^{8}$ Yet curiously, this attitude of critique was developed in such a way that the nation remained the framework for analysis. ${ }^{9}$ Australian studies courses frequently focused on a discussion of Australian national identity, without any consideration of the fact that other societies ponder and probe their own identity in much the same way Australians do, or without any awareness that these questions are not necessarily interesting for non-Australian students and readers.

There were many other associated shortcomings. Too often, courses focused mainly on the history and culture of the English-descended majority, and too little on the non-English peoples who have been so important a part of Australian history. With so many of the best female scholars preoccupied with the development of Women's studies (whose history has been roughly contemporaneous with that of Australian studies), Australian studies programs were usually devised and run by male scholars isolated from the advances being made by feminist scholarship. Too often, Australian studies courses focused too little on Indigenous histories and cultures, leaving them to the anthropologists and specialists in the somewhat separate field of Aboriginal studies. There are still very few Indigenous academics in Australia, and most of those are concentrated in education and Aboriginal studies programs.

Yet, if Australian studies courses in the past unwittingly promoted these stereotypes, by the later 1990s many courses were following new directions. For cultural, intellectual, and economic reasons, Australian studies is rapidly changing. The cultural reasons were most clearly exemplified in the opening ceremony of the Sydney Olympic Games in September 2000. For this millennial creation story, beamed to the world, the organizer of the ceremony, Australian Ric Birch (who, incidentally, also produced the opening ceremonies for the Los Angeles and Barcelona Olympic Games) drew on older stereotypes and combined them with newer images that Australians like to use when representing themselves to the rest of the world. Alongside images of the Australian rural worker, the farmer, the shearer, the pioneer-innovator struggling to build a new 
life in the Australian bush, and later the suburban male Australian mowing the lawn on his quarter-acre block, we saw colourful representations of multiculturalism, immigration, respect for and a desire to learn from ancient and continuing Indigenous cultures, and love of country and the sea. Symbolically, women athletes carried the Olympic torch around the stadium, and Cathy Freeman, a politically outspoken Indigenous woman, lit the flame in the Olympic cauldron.

Alongside these cultural changes have been intellectual developments which have permeated Australian studies across the country. The insights from Aboriginal studies and women's studies and cultural studies are being incorporated into Australian studies, to varying degrees, in different universities. There has been a rapid growth of interest in the history and culture of Indigenous peoples, in the study of gender and sexuality, and in the study of popular culture, to name the three that seem to me to be most important. Further, there have been economic policy reasons affecting the teaching of Australian studies. Some university administrators, aware of the potential attractions of Australian studies programs to both local and foreign students, have made some significant senior appointments in the field, and nurtured Australian studies programs even while other programs of study in the humanities and social sciences have, under financial pressure, been allowed to lapse. ${ }^{10}$

Australian studies programs, originally developed for Australian students, are currently in the process of adapting to the interests of students from overseas, especially the United States, and various countries in Asia, especially Japan. The "new" Australian studies—affected by cultural, intellectual, and economic desires and imperatives-thus seeks to go beyond the obsession with national character and national identity, and to engage in a conversation between Australian studies and other fields of study, however organized. The program at Australian National University (ANU), for example, while hard to characterize given the variety of people who teach it, places Australian studies in a variety of larger contexts, seeing Australia as a place where the histories and cultures of Europe, Asia, and Oceania meet. The program at the University of Melbourne has been developed with the needs of international students in mind, developing one course, "Exploring Central Australia," which includes fieldwork study in central Australia, and another which focuses on a comparison between Australia and the United States. 
Sometimes, the particular interests of overseas students can lead to new developments that benefit Australian students too. Overseas students, for example, have a great interest in antipodean landscape, plants, and animals, things Australian students in the humanities and social sciences frequently love and take for granted, but do not necessarily wish to study. Overseas student appreciation of these aspects of Australia is gradually leading those teaching Australian studies to include more study of Australian ecology and environment in their courses.

\section{The Future of Australian Studies}

I would like to end this essay on a somewhat personal note, as a supervisor of graduate students in Australian studies. For some students, interest in Australia begins in an undergraduate program in the student's own country-in economics, or literature, or history-and the student comes to Australia only when he or she has reached graduate level. Their aim is to undertake a research degree, at the master's or doctoral level, for which outstanding students can gain scholarships.

It is as a supervisor of these graduate research students, and coordinator of a graduate program in Australian studies, that I have been most able to practice a philosophy that perhaps meets Morris-Suzuki's concerns and my own longstanding interest: internationalizing and cosmopolitanizing Australian studies. In recent years, these students are changing not only their own lives, but also mine. At ANU, the graduate program in Australian studies is attracting three main groups-foreign students, local students of non-English-speaking background, and Indigenous students. Their topics of investigation reveal an international approach: consider Masayo Tada on "Australian Studies in Japan," Frances Peters-Little on "Aboriginal Involvement and Representation in Television Documentary," Thong Phoumirath on "Lao Wedding Ceremonies in Australia, the United States, and Laos," or Maribeth Cole on "Neil Davis: An Australian Photojournalist in Asia."

Some of my colleagues find it ironic that the Australian studies graduate program is one of the most culturally diverse in the university. I do not, because for me, Australian studies, at both undergraduate and graduate levels is an educational place ideally suited to bringing students of diverse origins from around the world and around the country together. 


\section{Notes}

1 Tessa Morris-Suzuki, “Anti-Area Studies," Communal/Plural, 8, 1, 2000, pp. 9-23.

2 Windows onto Worlds: Studying Australia at Tertiary Level: The Report of the Committee to Review Australian Studies in Tertiary Education, Canberra: Australian Government Publishing Service, 1987. Several Australian Studies Centres existed already, notably that of the University of Queensland, established in 1979. However, the Monash Centre was the largest and best-funded.

3 Examples include Deakin University, University of the Sunshine Coast, University of Newcastle, and Griffith University.

4 Examples include the University of Melbourne, University of Queensland, and Australian National University.

5 See Amanda Lohrey, Australian Studies Overseas : A Guide, Canberra : Australian Government Publishing Service, 1988.

6 Current international centres for Australian studies include the Menzies Centre for Australian Studies, King's College, University of London; Edward A. Clark Center for Australian Studies, University of Texas at Austin; Center for Australian and New Zealand Studies, Georgetown University; The Australia Centre, Potsdam, Germany; Centre For Australian Studies, University of British Columbia, Canada; Centre for Australian Studies in Wales, University of Wales at Lampeter; Australian Studies Centre, University of Barcelona, Spain; Australian Studies Centre, Beijing Foreign Studies University; Center for Australian Studies in Japan, Otemon Gakuin University.

7 Russell Ward, The Australian Legend, Melbourne: Oxford University Press, 1958, pp. 1-2.

8 James Walter, ed., Australian Studies-A Survey, Melbourne: Oxford University Press, 1989.

9 David Goodman, "The Promise of History," Australian Historical Association Bulletin, no. 78/79, Dec. 1994/Apr. 1995, pp. 43-47. 
10 Examples include Curtin University, University of Newcastle, and University of Queensland.

\section{Recommended Reading}

In the last few years, there has been an outpouring of "Companions" on aspects of Australian studies, and these are probably the best way to become acquainted with the field. Three of the most important are:

Barbara Caine et. al., eds, Australian Feminism: a Companion, Melbourne: Oxford University Press, 1998.

Sylvia Kleinert and Margo Neale, eds, The Oxford Companion to Aboriginal Art and Culture, Melbourne: Oxford University Press, 2000;

Stuart Macintyre, John Hirst, and Graeme Davison, eds, The Oxford Companion to Australian History, 1999;

On Aboriginal bistory and experience see also:

Grant Ngabitj: My Country of the Pelican Dreaming, [edited by Bruce Shaw], Canberra, 1981.

Charlie Perkins: A Bastard Like Me, 1975;

Henry Reynolds, The Other Side of the Frontier, 1981;

Henry Reynolds, Frontier, 1987;

Margaret Tucker: If Everyone Cared, Sydney, 1977;

For some other important academic texts aimed at university students see the following:

Robert Harold Fagan and Michael Webber, Global restructuring : the Australian experience, Melbourne : Oxford University Press, 1999;

Josephine Flood, Archaeology of the Dreamtime: The Story of Prebistoric Australia and Its People, Sydney: Angus \& Robertson, 1995;

John Frow and Meaghan Morris, eds, Australian Cultural Studies : A Reader, Sydney: Allen \& Unwin, 1993;

Stuart Macintyre, A Concise History of Australia, Cambridge University Press, 1999;

Jeremy Smith, ed, The Unique Continent : An Introductory Reader in Australian Environmental Studies, St. Lucia: University of Queensland Press, 1992;

Graeme Turner, National Fictions: Literature, Film, and the Construction of 
Australian Narrative, Sydney: Allen \& Unwin, 1986.

D.J. Walmsley and A.D. Sorensen, Contemporary Australia : Explorations in Economy, Society and Geography, Melbourne : Longman Cheshire, 1993;

Finally, read:

Phillip Bell and Roger Bell, Implicated: the United States in Australia, Melbourne: Oxford University Press, 1993. 